\title{
Tantangan dalam Penulisan Artikel Abstrak Penelitihan untuk Publikasi
}

\author{
Writing Research Article Abstract for Publication: Problems Encounter
}

\author{
Lailatul Khikmah \& Eri Kurniawan \\ Universitas Pendidikan Indonesia, Bandung, Jawa Barat, Indonesia \\ lailatulkhikmah1993@gmail.com
}

Naskah diterima tanggal 04/06/2020, direvisi akhir tanggal 28/06/2020, disetujui tanggal 30/08/2020

\begin{abstract}
Abstrak
Abstrak merupakan bagian pertama yang ditinjau oleh pembaca sebelum memutuskan untuk membaca sebuah penelitihan secara keseluruhan. Dalam praktiknya, penulisan abstrak dianggap mudah sehingga kadang kurang diperhatikan. Faktanya, menulis abstrak itu sangat susah karena banyak abstrak yang kurang berkualitas. Oleh karena itu, penelitihan ini secara khusus menganalisa secara mendalam mengenai permasalahan atau tantangan yang dihadapi oleh mahasiswa S2 dalam menulis abstrak. Peneliti menggunakan desain penelitihan kualitatif dengan melibatkan 10 orang mahasiswa S2 jurusan Bahasa Inggris di Universitas Pendidikan Indonesia yang telah berhasil mempublikasikan artikel mereka dalam skala internasional. Data ini dikumpulkan menggunakan kuesioner terbuka yang terdiri atas 4 item pertanyaan yang berkaitan. Dan dari hasil penelitihan diketahui bahwa kebanyakan mahasiswa (8 dari 10 orang) mengaku kesulitan untuk menulis abstrak yang informatif, efektif, padat, dan jelas dalam 250 kata. Sedangkan dua yang lainnya mengaku kesulitan menemukan penerbit yang cocok dan mengevaluasi kualitas abstrak yang ditulis sendiri. Oleh karena itu, untuk kedepannya mahasiswa diharapkan untuk mengikuti pelatihan ataupun konferensi mengenai penulisan abstrak yang baik, banyak membaca referensi dari jurnal yang terpercaya, dan berkonsultasi dengan ahli.
\end{abstract}

Kata kunci: Abstrak, Menulis Artikel, Tantangan

\begin{abstract}
Abstract is the first the readers reviewed before deciding to read the entire research. In practicality, writing an abstract is considered as an easy task which people sometimes less concerned. In fact, writing abstract is very challenging as many abstracts found to have a poor quality. Thusly, this research aims to deeply analyze the problems encounters by graduates'student in abstract writing. The researcher employed qualitative research and involved 10 graduates'students majoring English Education in the Indonesia University of Education who successfully published an article in international scale. The data then collected using open-ended questionnaire consisting of 4 correlated questions item. Additionally, the findings show that most of the students (8 out of 10 people) stated that the challenging part lies on writing an informative, effective, concise, and clear abstract in 250 words. While the other 2 states that it is hard to find a suitable publisher and to evaluate our own writing. Accordingly, it is suggested for them to follow some trainings or conference on writing a good abstract, reading a lot of samples from reputable journals, and have a consultation with the experts.
\end{abstract}

Keywords: Abstract, Challenges, Writing an Article

\section{PENDAHULUAN}

Menulis sebuah artikel abstrak penelitihan kerap dianggap sebagai sesuatu yang mudah dan sesuatu yang tidak terlalu penting sehingga banyak dari mahasiswa yang kurang memperdulikan kualitas hasil tulisan abstrak mereka dan hanya mengerjakan seadanya saja (Jalalian, 2012).
Faktanya penulisan abstrak sangat menantang (Papanas et al., 2012). Seperti yang dikatakan dalam sebuah penelitian yang dilakukan oleh Supatranont (2012). Hasil temuan penelitian tersebut mengemukakan bahwa banyak diantaranya mahasiswa Thailand yang gagal menulis abstrak yang baik dikarenakan oleh 
kurangnya pemahaman mengenai konten dan struktur mengenai abstrak itu sendiri.

Penelitihan tentang abstrak sebenarnya selalu menjadi penelitian yang dipilih dan menjadi penelitian yang favorit. Sayangnya banyak penelitian dalam abstrak yang dilakukan sebatas konten, tata Bahasa, diksi ataupun struktur abstrak itu sendiri seperti berikut. Çakır (2005) melakukan penelitian tentang perbandingan penggunaan tata bahasa dalam abstrak yang berfokus pada analisa kata keterangan (adverbs). Dalam penelitian ini dia melibatkan sekitar 240 abstrak yang ditulis oleh orang turki dan penutur Bahasa Inggris asli. Hasil dari penelitian ini menemukan bahwa penutur asli memiliki kencenderungan untuk menggunakan kata keterangan lebih banyak dalam abstrak yang mereka tulis.

Sejalan dengan penelitian sebelumnya Abdollahpour \& Gholami (2018) juga menganalisa abstrak dalam jumlah besar, yakni sebanyak 1500 abstrak. Bedanya pada penelitian ini, penulis menganalisa struktur umum yang biasa digunakan oleh penulis di jurusan ilmu kedokteran. Hasil penelitian kemudian menyeutkan bahwa kebanyakan abstrak mengunakan model Bunton (2002) yang merupakan adaptasi dari model Swales (2011) yang terdiri dari fokus penelitian, presentasi penelitian, deskripsi metode penelitian, dan ringkasan temuan penelitian. Oleh karena itu, peneliti tertarik untuk menganalisa permasalahanpermasalahan yang terjadi dalam proses penerbitan sebuah jurnal, khususnya persoalan tentang penulisan abstrak yang dialami oleh penulis yang sudah sukses menerbitkan artikel mereka dalam skala internasional seperti di jurnal yang sudah terindeks scopus ataupun di konferensi internasional. Sehingga, mahasiswa yang lain yang ingin menerbitkan artikel mereka bisa belajar dan mempersiapkan dengan baik untuk menangulangi permasalahan-permasalahan yang sering muncul.

\subsection{Definisi Abstrak}

Menurut pengertian secara literature, abstrak didefinisikan sebagai sebuah paragraf yang berisi 250 kata yang berfungsi untuk membantu pembaca memahami intisari dari penelitihan yang ditulis. Slade \& Perrin (2010) juga menyebutkan bahwa abstrak artikel merupakan kumpulan dari ringkasan tentang penelitian secara keseluruhan. Oleh karena itu, fungsi abstrak adalah untuk mendeskripsikan penelitian bukan untuk mengevaluasi ataupun mempertahankan klaim yang terdapat dalam artikel yang kita tulis. Secara struktur, Hyland (2013) menyebutkan bahwa abstrak harus berisi tentang isu seputar topik yang kita pilih (latar belakang dan tujuan penelitian) yang dideskripsikan dengan singkat, padat, dan jelas, metode penelitian, intisari dari temuan penelitian, dan kesimpulan. Selain hal tersebut, abstrak juga harus memiliki kata kunci yang mengarah kepada metode dan konten yang ada dalam penelitian. Slade \& Perrin (2010) juga menambahkan perbandingan contoh antara abstrak yang baik dan abstrak yang buruk sebagai berikut:

\begin{tabular}{|c|c|}
\hline $\begin{array}{l}\text { Bad abstract: } \\
\text { This paper will look at the human } \\
\text { genome project and its goals. I will } \\
\text { prove that scientists have ethical and } \\
\text { moral questions about genetic } \\
\text { engineering because of this project. }\end{array}$ & $\begin{array}{l}\text { Good abstract: } \\
\text { Begun in 1988, the human genome } \\
\text { project intends to map the } 23 \\
\text { chromosomes that provide the } \\
\text { blueprint for the human species. The } \\
\text { project has both scientific and ethical } \\
\text { goals. The scientific goals underscore } \\
\text { the advantages of the genome } \\
\text { project, including identifying and } \\
\text { curing diseases and enabling people } \\
\text { to select the traits of their offspring, } \\
\text { among other opportunities. Ethically, } \\
\text { however, the project raises serious } \\
\text { questions about the morality of } \\
\text { genetic engineering. To handle both } \\
\text { the medical opportunities and ethical } \\
\text { dilemmas posed by the genome } \\
\text { project, scientists need to develop a } \\
\text { clear set of principles for genetic } \\
\text { engineering and to continue } \\
\text { educating the public about the } \\
\text { genome project. }\end{array}$ \\
\hline
\end{tabular}

Gambar 1. Contoh abstrak yang baik dan buruk Slade \& Perrin (2010) 
Dari gambar tersebut kita tahu bahwa abstrak yang buruk tidak memasukkan latar belakang kepada pembaca mengenai human genome. Selain itu, metode penelitian yang digunakan juga tidak dideskripsikan dengan baik. Seperti yang tertera dalam contoh tidak ada keterangan mengenai desain, partisipan, ataupun metode pengumpulan data yang mana hal ini bisa menyebabkan kebingungan pada pembaca untuk memahami intisari dari penelitian yang kita tulis. Oleh karena itu, dari contoh abstrak yang baik kita tahu bahwa kita tidak seharusnya mengabaikan alur dari tulisan seperti rhetorical moves, yakni memulai tulisan kita dengan paragraf pembuka mengenai isu dan penulisan gap diantaranya.

\subsection{Menulis Abstrak untuk Publikasi}

Menulis untuk publikasi bisa sangat susah karena dia membutuhkan kemampuan tertinggi ataupun kemampuan yang mumpuni untuk membuat tulisan yang produktif (Murray \& Newton, 2008). Secara umum struktur penulisan abstrak bisa mengunakan standar 5 struktur seperti yang dikemukakan oleh Hyland (2013) yang mencakup latar belakang, tujuan penelitian, metode penelitian, hasil penelitian, dan kesimpulan ataupun mengunakan standar internasional PMRC yang mencakup tujuan, metode, temuan penelitian, dan kesimpulan.

$$
\text { Walden University }
$$
menyebutkan bahwa untuk meskipun jurnal atau artikel pada umumnya memiliki format ataupun pengaturan jumlah kata yang berbeda, Namun untuk punlikasi kita bisa mencontoh kerangka abstrak yang dikeluarkan oleh APA karena format ini diakui secara internasional sebagai rujukan untuk menulis abstrak yang baik. Selain itu, untuk strategi menulis agar tulisan kita diterima. Kita juga harus memastikan bahwa tulisan kita bebas dari kesalahan penggunaan tata bahasa (Walden University, 2020). Abstrak yang bagus menggunakan present tense untuk mendeskripsikan temuan penelitian yang masih berlaku sampai saat ini. Contohnya result indicate... dan menggunakan past tense untuk menjabarkan langkah-langkah penelitian misalnya the data collected....
Hal terpenting yang perlu diingat lagi adalah dalam menulis abstrak tidak disertakan kutipan. Meskipun sudah ada pengaturan ataupun saran dalam penulisan abstrak. Pada kenyataannya mahasiswa masih mengalami kesulitan dalam menulis abstrak. Oleh karena itu, penelitian ini mengulik lebih dalam mengenai permasalahan-permasalahan apa saja yang mereka hadapi.

\section{METODE PENELITIAN}

Desain penelitian penelitian ini menggunakan desain penelitian kualitatif karena tujuan utama dari penelitian ini adalah menganalisis secara mendalam permasalahan apa saja yang sering kali dihadapi oleh mahasiswa dalam menulis abstrak untuk publikasi jurnal atau artikel yang umumnya terdiri dari 250 kata secara maksimal. Oleh karena itu, desain penelitian ini dipilih oleh peneliti karena proses penjabaran data dari desain kualitatif dikupas lebih mendalam yang mana hal tersebut berkesinambungan dengan tujuan penelitian ini karena desain ini bisa mempermudah peneliti untuk melakukan data analisis dan pembahasan dari hasil penelitian (Paris \& Winn, 2018).

Partisipan dalam penelitian ini adalah 10 mahasiswa pascasarjana jurusan pendidikan Bahasa Inggris di Universitas Pendidikan Indonesia angkatan 2017 berpartisipasi dalam penelitian ini, khususnya mahasiswa penerima beasiswa yang berhasil menerbitkan artikel atau jurnal yang terindeks Scopus ataupun yang telah mempresentasikan dan menerbitkan artikel penelitian dalam skala konferensi internasional.

Pemilihan 10 partisipan dalam penelitian ini didasari karena kemampuan akademik yang mereka miliki sangat baik dan performa mereka di dalam kelas di atas ratarata. Oleh karena itu, keterlibatan mereka dalam penelitian ini diharapkan bisa berbagi pengalaman sekaligus memberikan informasi yang lebih mendalam tentang tantangan apa saja yang mereka hadapi dalam menulis artikel atau jurnal untuk publikasi. Selain itu, keterlibatan 10 partisipan juga diharapkan bisa memberikan data yang lebih spesifik dan menghasilkan data representatif. Hal ini 
sejalan dengan penelitian yang dilakukan oleh Fadhly et al., (2018) yang hanya melibatkan 5 orang partisipan dalam penelitiannya.

Oleh karena itu juga peneliti hanya menggunakan satu jenis instrument berupa pertanyaan atau kuesioner terbuka (openended questionnaire) yang terdiri dari 4 item pertanyaan yang berhubungan dengan tantangan menulis abstrak untuk publikasi, materi pembelajaran cara menulis akademik yang diberikan di universitas, dan ekpektasi dari mahasiswa untuk tujuan kemajuan pengajaran penulisan akademik kedepannya.

Dalam pengumpulan data yaitu data respons pertanyaan atau kuesioner terbuka (open-ended questionnaire). Pertamatama peneliti mengumpulkan data tersebut menggunakan sampling kemudahan (convenience sampling) dengan mengontak partisipan secara langsung untuk menanyakan tentang ketersediaan mereka untuk turut berpartisipasi dalam penelitian ini. Setelah adanya persetujuan, peneliti menggunakan google form untuk mempermudah proses pengumpulan data secara daring yaitu dengan membagikan pranala lewat pesan secara pribadi menggunakan WhatsApp ke nomor masing-masing partisipan. Untuk batas pengumpulan terakhir data kuesioner terbuka paling lambat dikirimkan 2 minggu setelah selang waktu yang disetujui antara peneliti dan partisipan. Hal ini dilakukan karena peneliti harus menyesuaikan dengan jadwal kesibukan mereka dan memberikan mereka waktu yang cukup untuk berpikir tentang respons seperti apa yang harus mereka tulis dan untuk menghindari jawaban yang asalasalan.

Data yang diperoleh kemudian dianalisis menggunakan 4 langkah, yaitu kode, kategori, analisis, dan interpretasi (Ary et al., 2014). Jadi, data yang diperoleh dari kuesioner terbuka kemudian dikodekan untuk menemukan data yang dibutuhkan yang berhubungan dengan pertanyaan penelitian. Setelah tahap pengkodean, data kemudian dikonseptualisasikan atau dikategorikan sesuai dengan kesamaan konten. Selanjutnya data dianalisis sesuai dengan kebutuhan untuk menjawab pertanyaan penelitian yang berhubungan dengan tantangan dalam menulis artikel abstrak penelitian. Tahap terakhir adalah data diinterpretasikan secara lebih mendalam sehingga peneliti bisa menarik sebuah kesimpulan dari hasil interpretasi.

\section{HASIL DAN PEMBAHASAN 3.1. Hasil}

Seperti yang disebutkan sebelumnya bahwa penelitian ini menggunakan kuesioner terbuka untuk menjawab pertanyaan penelitihan sebagai berikut: (1) Apa sajakah tantangan atau permasalahan yang dihadapi oleh mahasiswa pascasarjana dalam menulis artikel abstrak penelitian untuk publikasi?. Untuk menjawab pertanyaan penelitian tersebut, peneliti mengumpulkan data kuesioner dari 10 orang mahasiswa penerima beasiswa jurusan Pendidikan Bahasa Inggris angkatan 2017 di Universitas Pendidikan Indonesia yang telah berhasil mempublikasikan artikel atau jurnal dalam skala Scopus ataupun konferensi internasional. Akan tetapi, nama-nama mahasiswa tersebut akan diganti dengan A1-A10. Respon jawaban yang didapat diharapkan bisa menjawab pertanyaan penelitihan yang disebutkan di atas. Untuk itu peneliti juga memasukkan beberapa pertanyaan yang berkaitan dengan pertanyaan utama penelitian seperti yang disebutkan sebagai berikut:

\section{Strategi menulis apa sajakah yang anda gunakan sehingga tulisan anda bisa berpeluang dan diterima untuk dipublikasikan?}

Pertanyaan ini diajukan untuk mengetahui gaya menulis seperti apa yang spesifik mereka lakukan karena mereka telah berhasil mempublikasikan artikel atau jurnal penelitian mereka dalam skala Scopus ataupun konferensi internasional. Pertanyaan ini juga diajukan karena pertanyaan utama penelitian ini adalah tentang permasalahan yang mereka hadapi dalam menulis sebuah artikel atau jurnal untuk publikasi internasional. Sehingga, diperlukan juga pertanyaan lanjutan mengenai bagaimana cara mereka untuk mengatasi masalah- 
masalah yang terjadi. Semua jawaban dari pertanyaan ini dijelaskan sebagai berikut:

\section{Kutipan 1:}

"Selain memastikan bahwa tulisan kita bebas dari kesalahan tatanan kata dan kesalahan penggunaan kosa kata ataupun terminologi, saya juga memastikan bahwa topik yang saya tulis tersebut masih layak untuk diteliti contohnya seperti topik-topik yang masih hangat dan laporan-laporan penelitian yang sudah dipublikasikan dalam jurnal yang terpercaya".

(A1)

"Pertama-tama, saya harus menyesuaikan tulisan saya dengan tema isu-isu yang utama selanjutnya saya banyak menggunakan jurnaljurnal dari sumber yang sudah terpercaya sebagai sumber referensi dari tulisan saya.”

(A2)

"Mencari sebuah celah penelitian di dalam isu-isu penelitian yang terbaru kemudian menulis signifikansi dari penelitihan yang kita lakukan. Hal yang terpenting lainnya adalah kita harus menunjukkan atau memasukan referensi yang bagus dari jurnal-jurnal yang terpercaya untuk menguatkan, menjustifikasi, ataupun mendukung tulisan yang kita buat. Contohnya seperti berikut:"Despite a growing interest on L2 writing in higher education (e.g. Tesol Quarterly, 2018; Language Learning, 2011; System, 2019; Applied Linguistics, 2009), a relatively few attention has been given on the graduate student abstract writing (RELC, 2010; ELT Journal, 2013; Second Language Writing, 2019)." Setelah itu, baru kita tuangkan ide kita dalam bentuk tulisan secara sederhana, langsung ke inti masalahnya dan tidak bertele-tele secara jelas dan bervariasi untuk menghindari pemilihan kata yang tidak perlu yang dapat membuat tulisan kita berkesan penuh dan bertele-tele."

"Strategi yang saya lakukan adalah dengan memperbaiki tulisan saya berdasarkan masukan yang saya dapat dari pengulas jurnal."

(A4)

"Dengan memilih topik-topik penelitihan yang lagi ramai dilakukan dan menulis judul penelitian yang menarik perhatian."

(A5)

"Strategi yang saya lakukan adalah menulis sebuah topik penelitian yang telah ditentukan oleh penerbit seperi scopus ataupun topik yang ditentukan oleh konferensi internasional. Setelahnya, saya baru menulis dan meneliti hal terbaru yang sesuai dengan tema penelitian yang diwajibkan.”

(A6)

"Dengan mencari sebuah celah dalam penelitian kita dan mencari penerbit yang sekiranya berpeluang untuk menerbitkan tulisan saya yang sesuai dengan topik yang saya teliti."

"Dengan menggunakan kosa kata yang akademik yang sekiranya bisa mudah dipahami oleh semua tipe pembaca jurnal."

(A8)

"Dengan menuliskan topik penelitian yang lagi hangat."

"Menjelaskan celah dari penelitian kita secara jelas."

(A10)

Dari jawaban-jawaban yang disebutkan di atas, kita mengetahui bahwasanya hampir secara keseluruhan mahasiswa tersebut sepakat bahwa strategi yang mereka lakukan untuk membuat tulisan atau artikel mereka berpeluang tinggi untuk dipublikasikan secara internasional adalah dengan menuliskan topik-topik penelitian yang terbaru yang bebas dari kesalahan ejaan ataupun tata Bahasa (A1, A2, A3, A5, A9). Sedangkan mahasiswayang lain menyebutkan bahwa mencari dan mempresentasikan sebuah celah dari penelitian kita secara jelas, menggunakan format tulisan dan topik yang telah ditentukan oleh penerbit, hanya menggunakan Bahasa-bahasa tulisan yang akademik, ataupun merevisi tulisan dalam artikel kita sesuai dengan saran dan masukan dari pengulas jurnal adalah hal utama yang dilakukan untuk membuat tulisan saya berpeluang untuk dipublikasikan secara internasional (A4, A6, A7, A8, A10).

Jelaskan apa sajakah tantangan yang kalian hadapi dalam menulis sebuah artikel abstrak penelitian yang layak ataupun yang cukup bagus untuk dipublikasikan?

Pertanyaan ini merupakan pertanyaan utama dari penelitian ini yaitu mengenai tantangan dalam menulis sebuah abstrak penelitihan dalam artikel ataupun jurnal untuk publikasi. Harapan dari diajukannya pertanyaan ini adalah untuk berbagi pengalaman kepada mahasiswa atau 
pembaca lain yang berharap artikel atau tulisan penelitian mereka bisa diterima untuk dipublikasikan secara internasional. Sehingga mahasiswa yang lain bisa belajar menyiapkan dan berpikir kritis mengenai strategi khusus yang mereka lakukan untuk menghadapi masalah yang sama dikemudian hari. Dari hasil kuesioner terbuka, peneliti menemukan jawaban yang berbeda dari A1A10 seperti yang bisa dilihat sebagai berikut:

\section{Kutipan 2:}

"Tantangan yang saya hadapi saat menulis abstrak dari sebuah artikel untuk keperluan publikasi adalah memastikan semua poin penelitian saya tercakup semua dalam abstrak yang saya tulis. Selain itu memastikan bahwa Bahasa tulisan yang kita gunakan menarik untuk dibaca lebih lanjut adalah hal yang paling susah."

\section{(A1)}

"Mendeskripsikan semua elemen yang terkandung dalam abstrak seperti latar belakang, tujuan, temuan penelitihan, dan kesimpulan hanya dalam 250 kata adalah tantangan yang sangat berat dalam menulis abstrak dari sebuah artikel khususnya untuk keperluan publikasi secara internasional."

\section{(A2)}

"Mendeskripsikan secara singkat dan memasukkan semua bagian-bagian abstrak dari latar belakang sampai kesimpulan dan menulis hal tersebut menjadi sebuah kalimat yang memiliki kohesi dan koherensi."

\section{(A3)}

"Menulis abstrak yang informatif dengan jumlah kata yang terbatas."

\section{(A4)}

"Menulis abstrak dengan jumlah kata yang terbatas dan menyesuikan dengan tuntutan yang diberikan oleh penerbit dan mengubah gaya tulisan kita sesuia dengan format yang telah disediakan adalah hal yang paling susah karena kita perlu lebih banyak waktu lagi dalam proses editing padahal publikasi tersebut juga memiliki batas waktu pengumpulan."

\section{(A5)}

"Menurut saya bagian yang paling susah dari menulis abstrak untuk keperluan publlikasi adalah menulis semua poin-poin dalam penelitian kita secara jelas namun dengan jumlah kata yang terbatas."

(A6)

"Permasalahan dan tantangan terberat bagi saya adalah mencari penerbit yang bisa menerbitkan artikel kita. Maksudnya adalah mencari penerbit yang menerbitkan artikel yang sesuai dengan judul yang kita tulis atau teliti."

"Bagi saya menggunakkan tata Bahasa ataupun kosa kata akademik yang sekiranya bisa dimengerti oleh semua jenis pembaca adalah hal yang paling susah."

(A8)

"Sebenarnya saya tidak begitu mengetahui aturan umum dalam penulisan abstrak dalam sebuah artikel. Biasanya saya menulis setelah membaca banyak referensi dari jurnal-jurnal terpercaya tanpa mengetahui apakah tulisan yang saya buat tersebut ditulis dengan baik ataupun tidak. Yang pastinya saya melakukan yang terbaik dari yang saya bisa lakukan."

(A9)

"Membuat abstrak yang sistematik, memiliki koherensi antar kalimat yang baik, yang mudah dimengerti oleh semua jenis pembaca, dan hanya menuliskan poin penting namun informatif adalah hal yang tidak mudah."

(A10)

Dari semua jawaban-jawaban hasil dari kuesioner terbuka ditemukan bahwasannya hampir semua dari mahasiswa yang telah berhasil mempublikasi artikel ataupun jurnal penelitihan mereka dalam skala internasional memiliki kesulitan masalah yang sama seperti halnya memasukkan semua bagian abstrak dari latar belakang sampai kesimpulan dalam jumlah kata yang terbatas yakni 250 kata paling banyak dan membuat tulisan tersebut menjadi tulisan yang cukup jelas merepresentasikan keseluruhan dari penelitihan kita adalah hal yang paling susah untuk dilakukan (A1, A2, A3, A4, A5, A6, dan A10). Dengan kata lain 7 dari 10 orang mahasiswa mengatakan masalah yang sama. Sedangkan A7 mengungkapkan masalah yang berbeda yakni kesulitan untuk menemukan penerbit yang mempublikasikan artikel dengan topik yang sama dengan penelitian yang kita lakukan adalah hal yang tersulit. A8 disisi lain menambahkan masalah lain yang bisa saja muncul seperti menentukan untuk hanya menggunakkan kosa-kata dan tata Bahasa yang akademik yang juga mudah dimegerti oleh semua tipe pembaca adalah hal yang paling susah. A9, juga menambahkan bahwa mencari contoh penulisan abstrak yang baik di internet untuk 
dijadikan sebagai acuan penulisan adalah hal yang paling susah karena kita tidak bisa menilai hasil setelahnya apakah tulisan yang kita tulis menghasilkan kualitas abstrak yang baik dalam pandangan skala internasional.

\section{Apakah materi pembelajaran Bahasa Inggris yang diajarkan di Universitas membantu anda dalam menulis akademik seperti menulis sebuah abstrak yang baik dalam Bahasa Inggris? Materi seperti apa yang kalian dapatkan? Tolong dijelaskan!}

Pertanyaan ketiga ini diajukan karena dianggap masih relevan dengan pertanyaan utama tentang tantangan yang dihadapi mahasiswa S2 dalam menulis sebuah abstrak untuk publikasi. Oleh karena itu pertanyaan ini dimaksudkan untuk mencari akar permasalahan yang dihadapi dan juga untuk memberikan ulasan materi penulisan akademik yang disediakan di Universitas, yaitu seberapa jauh materi pembelajaran yang diberikan di Universitas membantu dalam penulisan abstrak. Oleh karenanya semua jawaban atas pertanyaan di atas dijelaskan secara rinci melalui kutipan pernyataan sebagai berikut:

\section{Kutipan 3:}

"Materi yang diberikan tidak terlalu membatu karena kebanyakan pengajaran cara menulis abstrak hanya sebatas menyebutkan tentang hal apa saja yang harus dimasukaan ke dalam abstrak tanpa adanyanya penjelasan bagaimanakah cara menuliskan poin-poin dari latar belakang sampai ke kesimpulan yang baik."

\section{(A1)}

"Sepengetahuan saya, saya tidak pernah mendapatkan materi dalam penulisan akademik yang secara khusus mengajarkan tentang cara penulisan abstrak yang baik dari masa saya mengambil kuliah jurusan Bahasa Inggris dari zaman S1. Akan tetapi beberapa mata kuliah yang saya ambil di S2 mengajarkan tentang cara penulisan artikel ataupun jurnal seperti caranya mencari sebuah celah penelitian, cara menuliskan metode penelitihan, cara menulis temuan penelitian, dan juga cara menarik sebuah kesimpulan."

\section{(A2)}

"Mata kuliah penulisan akademik yang diajarkan di Universitas khususnya tentang penulisan abstrak biasanya hanya sebatas penyebutan poin yang harus dituliskan dalam abstrak tanpa penjelasan yang lebih lanjut mengenai bagaimana penulisan abstrak yang baik."

"Iya mencakup materi penulisan abstrak karena dijelaskan tentang aspek-aspek apa saja yang harus dimasukkan dalam menulis sebuah abstrak seperti contohnya materi yang saya dapat dari matakuliah research method, research project, qualitative research, dan qualitative data analysis. "

(A4)

"Materi yang diberikan tidak terlalu membantu untuk penulisan abstrak yang baik karena kebanyakan matakuliah yang diajarkan di penulisan akademik lebih berfokus tentang pengajaran bagaimana cara menuliskan kajian pustaka dan metode dalam penelitian. Pengajaran tentang cara menulis sebuah abstrak hanya sebatas memberitahu mahasiswa mengenai aspek apa sajakah yang harus dituliskan. Hanya itu."

"Iya membantu, seperti misalnya mata kuliah EFL methodology. Akan tetapi pengajaranya hanya sebatas penjelasan mengenai poinpoin penting yang harus ditulisakan dalam abstrak."

(A6)

"Tidak terlalu membantu karena biasanya hanya mencakup poin-poin penting saja yang harus dimasukkan dalam penulisan abstrak."

(A7)

"Materi perkuliahan tentang penulisan abstrak hanya mencakup tentang poin apa saja yang harus dimasukkan dalam menulis sebuah abstrak."

(A8)

"Sepanjang yang saya ketahui, materi-materi perkuliahan tentang penulisan abstrak hanya diajarkan secara implicit."

(A9)

"Tidak terlalu karena kita hanya mempelajari tentang aspek seperti apa saja yang harus dituliskan dalam menulis sebuah abstrak tanpa adanya evaluasi tentang abstrak yang kita tulis."

(A10)

Dari hasil pernyataan yang didapat dari kuesioner terbuka dapat kita simpulkan bahwa semua mahasiswa (10 dari 10 orang) setuju bahwa matakuliah penulisan akademik dalam Bahasa inggris yang tersedia di Universitas tidak terlalu membantu khususnya untuk menulis abstrak yang baik 
karena materi tersebut hanya diajarkan secara implicit. Selain itu terkadang penjelasan tentang hal tersebut terlalu singkat dan hanya sebatas tentang struktur umum penulisan abstrak yakni mencakup latar belakang, tujuan, metode penelitian, hasil penelitihan, dan kesimpulan. Evaluasi ataupun masukan tentang kualitas penulisan abstrak mahasiswa tidak pernah dilakukan jadi mahasiswa mengalami kesulitan untuk menentukan apakah sebenarnya abstrak yang mereka tulis sudah bagus atau tidak (A1, A2, A3, A4, A5, A6, A7, A8, A9, dan A10).

\section{Materi penulisan akademik seperti apa untuk ke depannya yang kalian harapkan didapatkan dari dosen Bahasa inggris?}

Pertanyaan ini diajukan karena masih relevan dengan pertanyaan sebelumnya dan dianggap bisa memberikan masukan dari sudut pandang mahasiswa mengenai materi pembelajaran yang diajarkan untuk kemajuan pengajaran menulis akademik dalam Bahasa inggris di Universitas seperti memberikan ide materi seperti apa yang perlu ditambahkan dan dikurangi dalam pembelajaran menulis akademik berdasarkan permasalahan yang terjadi. Hasil jawaban untuk pertanyaan ini cukup bervariasi seperti yang disebutkan sebagai berikut:

\section{Kutipan 4:}

"Tambahan materi seperti cara penulisan abstrak yang jelas and cara untuk menuliskan bagian pembahasan dalam penelitian karena hal ini menurut saya adalah bagian yang paling penting dalam sebuah penelitian. Faktanya, materi tentang hal ini tidak diajarkan secara extensive. Oleh karena itu, pada beberapa kasus penulisan bagian pembahasan misalnya hanya berisi tentang pengulangan dari temuan penelitian."

(A1)

"Semua aspek tentang cara melaporkan atau menjabarkan penelitian dengan baik seperti salah satu contohnya adalah mengajarkan cara penulisan abstrak yang efektif dan informative."

"Sebaiknya untuk kedepannya juga diajarkan cara mengemukakan ide dalam bentuk tulisan yang tidak bertele-tele dan tepat sasaran."

(A3)
"Kedepannya diharapkan para dosen untuk mengajarkan semua aspek-aspek penting dalam menulis sebuah penelitian yang tidak hanya dibatasi dengan mengajarkan struktur umum ataupun gaya penulisan sebuah penelitian tapi juga memasukkan materi tentang konten apa sajakah yang harus ditulis pada bagian abstrak sampai dengan kesimpulan. Jika tidak memungkinkan untuk mengajarkan tentang hal tersebut pada 1 semester maka ada baiknya materi kelanjutannya ditambahkan pada semester berikutnya."

"Saya berharap untuk kedepannya pengajaran tentang tata cara penulisan akademik tidak hanya difokuskan pada hasil akhir (produk tulisan mahasiswa) tapi juga memperhatikan proses atau tahapan-tahapan kemajuan penulisan yang telah dilalui oleh mahasiswa."

(A5)

"Menurut saya materi seperti cara untuk menulis sebuah artikel yang layak untuk dipublikasikan perlu juga untuk diajarkan seperti juga misalnya cara-cara untuk menulis sebuah abstrak dalam artikel penelitian yang informatif dan sekiranya bisa membuat pembaca tertarik untuk membaca lebih lanjut keseluruhan dari penelitihan kita."

(A6)

"Saya berharap untuk kedepannya siswa bisa mendapatkan materi tentang penulisan thesis yang efektif mulai dari penulisan abstrak sampai dengan bagian penarikan kesimpulan seperti materi yang pernah disampaikan oleh pak Widodo Handoyo, pemateri yang diundang untuk memberikan kuliah tamu."

(A7)

"Ada baiknya bila dosen juga memasukan pengajaran tentang semua aspek-aspek penting dalam penulisan akademik."

(A8)

"Menjelaskan tentang strategi yang lebih spesifik lagi mengenai cara-cara untuk mengekspresikan ide-ide kita ke dalam bentuk tulisan secara akurat dan tepat."

(A9)

"Untuk mengajarkan mata kuliah tentang penulisan artikel yang mudah untuk dipahami secara alur idenya, struktur kalimatnya, dan lain-lain."

(A10)

Berdasarkan hasil jawaban yang dicantumkan di atas, peneliti menemukan bahwa beberapa mahasiswa mengajukan saran yang sama yaitu sebanyak 7 dari 10 orang. Mereka pada dasarnya mengemukakan 
saran yang sama yakni untuk memasukkan semua materi penting yang berhubungan dengan penulisan tentang deskripsi penelitian seperti contohnya mengajarkan materi tentang penulisan abstrak sampai dengan penarikan kesimpulan yang jelas dan bersifat informative (A1, A2, A4, A6, A7, A8, dan A10). Sementara A3, A5, dan A9 menyarankan untuk memberikan matakuliah yang sekiranya bisa membantu untuk mengekspresikan sebuah ide secara tepat dan tidak bertele-tele. Selain itu A5 juga secara khusus menyarankan para dosen untuk tidak hanya berfokus ke hasil akhir (produk tulisan) tapi juga menimbang dan menginvestigasi proses penulisan mahasiswa sehingga dosen bisa memberikan saran mengenai apa yang perlu ditingkatkan dan dipertahankan dari tulisan tersebut.

Jadi, kesimpulan dari temuan penelitian ini adalah masing-masing mahasiswa ratarata memiliki permasalahan yang hampir sama dalam proses mempublikasikan artikel atau jurnal mereka dalam skala internasional. Kebanyakan dari mahasiswa tersebut menyebutkan bahwa tantangan menulis abstrak untuk publikasi terletak pada bagian meringkas semua intisari dari penelitian yang kita lakukan dengan mendeskripsikannya menjadi paling banyaknya sepanjang 250 kata.

\subsection{Pembahasan}

Berdasarkan hasil dari temuan penelitian, bagian pembahasan akan secara khusus menjelaskan dan mendiskusikan pertanyaan utama penelitian ini yakni mengenai: (1) Apa sajakah tantangan atau permasalahan yang dihadapi oleh mahasiswa pascasarjana dalam menulis artikel abstrak penelitian untuk publikasi?. Untuk melihat lebih dalam mengenai permasalahan yang dihadapi mahasiswa S2 jurusan Bahasa Inggris dalam proses penerbitan artikel atau jurnal penelitian mereka khususnya mengenai penulisan pada bagian abstrak penenelitian.

Detail analisis mengenai hal tersebut dikupas dan dikategorikan berdasarkan jenis permasalahannya ke dalam beberapa subab seperti berikut:

\section{a. Meringkas keseluruhan penelitian menjadi 250 kata}

Merujuk kepada teori Hyland (2013) abstrak harus mencakup 5 aspek meliputi latar belakang, tujuan, metode penelitian, hasil penelitian, dan kesimpulan. Oleh karena itu secara mayoritas mahasiswa sebanyak 7 dari 10 orang (A1, A2, A3, A4, A5, A6, dan A10) mengatakan bahwa bagian paling susah dalam menulis abstrak adalah bagaimana mendeskripsikan semua aspek tersebut dari latar belakang sampai penarikan kesimpulan hanya dengan 250 kata. Oleh karena itu, Georgia Mansion University (2020) menyebutkan porsi dari penulisan bagianbagian tersebut, 25\% dari abstrak, yakni sekitar 62-63 kata harus mencakup penulisan latar belakang penelitian yang mencakup tujuan dan signifikansi dari penelitian yang kita lakukan, 25\% sisanya, sekitar 62-63 kata mencakup deskripsi mengenai metode yang berisi tentang penjelasan mengenai desain, partisipan, dan cara mengumpulkan dan analisis data, 35\% lainnya, yakni sekitar 87 kata digunakan untuk mendeskripsikan hasil penelitian secara keseluruhan, dan sebanyak 15\% sisanya, yaitu sekitar 37 kata digunakan untuk mendeskripsikan bagian kesimpulan ataupun implikasi dari penelitihan.

Hyland (2013) juga menyebutkan bahwa konten yang harus tercakup dalam bagian latar belakang adalah argumen mengenai fokus, relevansi, tujuan, dan pentingnya penelitian yang kamu lakukan. Hal ini sejalan dengan pemikiran yang dikemukakan oleh Andrade (2011) bahwa latar belakang penelitian harusnya mencakup 2 aspek yaitu apa yang sudah diketahui atau ditemukan dalam topik yang anda pilih (isu-isu yang terbaru) dan apa yang belum diketahui tentang topik tersebut (gap) yang akan anda teliti. Secara umum, bagian latar belakang harus mencakup paling banyak 2-3 kalimat. Secara teori, bagian ini biasanya diawali dengan mendeskripsikan masalah yang hangat yang terjadi seputar topik penelitian yang dipilih dan setelahnya diikuti dengan fokus dan tujuan penelitian yang anda lakukan. Untuk menyambungkan bagian isu ke fokus ataupun tujuan penelitihan Hyland (2009) menyebutkan bahwa penulis bisa menggunakan frase 
yang bisa digunakan untuk beralih dari satu pemikiran ke pemikiran yang lainnya (signal words) seperti furthermore, "this research investigates...." Agar pembaca bisa mengetahui dan memahami dengan jelas dan baik alur dari abstrak yang anda tulis.

Bagian metode penelitian, Hyland (2013) menyebutkan bahwa harusnya mengandung informasi yang cukup mengenai metode, partisipan, dan cara pengumpulan data. Sedangkan untuk temuan penelitian Hyland (2009) juga menyebutkan bahwa bagian ini harus mencakup hasil temuan penelitian secara umum. Dengan kata lain, bagian ini harus benar-benar bisa merepresentasikan detail temuan penelitian dengan melakukan parafrase kata yang jelas dan singkat. Biasanya bagian ini diawali dengan frase seperti: "The data indicates..." or "We found...". Yang terakhir adalah bagian kesimpulan. Andrade (2011) mengatakan bahwa bagian ini biasanya menyoroti hasil utama dari penelitian yang anda lakukan dengan melakukan penarikan kesimpulan, menyatakan implikasi teoritis atau praktis tentang pentingnya penelitian ini untuk bidang tertentu, ataupun berisi tentang rekomendasi untuk penelitian selanjutnya. Oleh karenanya, bagian kesimpulan pada abstrak harus jelas dan konsisten dimana penulis tidak melakukan klaim tambahan di luar data yang dideskripsikan.

Dengan mengikuti struktur penulisan ini, penulis jurnal diharapkan bisa lebih fleksibel dan mudah untuk menulis poin-poin penelitian dalam 250 kata (Prihatmi, 2017). Batasan kata dalam abstrak ini bertujuan untuk membantu penulis untuk membuang kata-kata yang tidak perlu dan mengurangi deskripsi panjang yang bertele-tele (Forester et al., 2018). Meskipun demikian, beberapa penulis masih mengalami kesulitan untuk mendeskripsikan keseluruhan dari penelitian menjadi 250 kata. Oleh karena itu, Foote (2006) merekomendasikan para penulis untuk menggunakan gaya tulisan yang sama yang tertera pada artikel yang kita tulis, mengindari jargon, menggunakkan kalimat lengkap, mengunakan kata transisi untuk mempertahankan koherensi antar kalimat, dan tidak menambahkan informasi-informasi yang tidak penting. Hyland \& Tse (2005) juga menyebutkan bahwa untuk membuat abstrak yang infomatif hanya dengan 250 kata, kita bisa menulis abstrak setelah semua bagian dari penelitian selesai ditulis kemudian kita membuat kesimpulan dari masing-masing bagian yakni dari latar belakang sampai dengan kesimpulan dengan 250 kata dan kemudian memparafrasekan kata tersebut menjadi sebuah kalimat.

\section{b. Mencari Penerbit yang sesuai dengan topik yang diteliti}

Dari temuan penelitihan A7 secara spesifik menyebutkan hal yang paling susah adalah mencari penerbit yang menerbitkan artikel yang sesuai dengan topik yang kita pilih. Untuk itu Hyland (2013) menyarankan pada para mahasiswa untuk menentukan dimana akan kita terbitkan artikel kita dan kemudian menyesuaikan gaya tulisan kita juga topik yang diteliti sesuai dengan ketentuan yang diberikan oleh penerbit. Selain itu, kita juga disarankan untuk meneliti topik-topik yang terbaru sehingga mudah bagi kita untuk mengirimkan jurnal yang kita tulis ke penerbit yang lain jika tulisan kita gagal dimuat di penerbit sasaran kita yang pertama. Oleh karena itu, kesusahan yang dikemukan oleh A7 bisa dikarenakan topik yang diteliti bukan topik-topik yang lagi hangat jadi susah untuk mencari penerbit yang sesuai.

\section{c. Mencari contoh abstrak yang baik dari internet}

Mencari contoh abstrak-abstrak yang baik dalam internet sebenernya mudah jika kita tahu kemana kita harus mencari. Banyak sumber terpercaya seperti Science direct, Tesol, Elsevier dan lainlain yang bisa dicontoh format penulisan abstraknya. Setelahnya kita bisa menganalisa apakah abstrak tersebut secara konten dan strukturnya sudah mengacu pada standar penulisan abstrak secara internasional seperti menggunakan model Hyland (2013) ataupun PMRC. Baru setalah yakin abstrak yang ditulis sudah cukup bagus, peneliti bisa menggunakan abstrak tersebut sebagai contoh penulisan. Apabila masih bingung, mahasiswa bisa langsung berkonsultasi 
dengan dosen academic writing mengenai sumber-sumber terpercaya yang menyajikan abstrak dengan kualitas penulisan yang baik dan menarik.

\section{d. Strategi untuk menghadapi permasalahan terkait publikasi}

Seperti yang disebutkan di bagian temuan penelitian, masalah umum yang dihadapi mahasiswa terkait publikasi adalah berhubungan dengan meringkas semua poin-poin penting penelitian ke dalam 250 kata. Oleh karena itu, 5 dari 10 mahasiswa yang sukses mempublikasikan artikelnya memanfaatkan masukan atau kritikan yang diberikan oleh dosen pembimbing ataupun pengulas jurnal dengan memperbaiki tulisan tersebut sesuai saran dari mereka.

\section{KESIMPULAN}

Menulis sebuah abstrak dalam jurnal yang berskala internasional bukan suatu perkara yang mudah. Ada banyak hal yang perlu untuk diperhatikan. Salah satunya tantanganuntukmembuatsebuah abstrakyang informatif hanya dalam 250 kata, mengikuti gaya penulisan yang telah ditentukan penerbit, ataupun mencari peluang penerbit yang bisa menerbitkan jurnal kita. Oleh karena itu, diharapkan untuk kedepannya mahasiswa bisa mengembangkan diri dengan mengikuti pelatihan cara penulisan jurnal yang baik dari bagian abstrak sampai dengan kesimpulan, lebih kritis untuk melihat contoh abstrak yang sudah dipublikasikan secara daring karena tidak semua abstrak yang tersedia memiliki kualitas yang baik. Oleh karena itu, disarankan juga kepada mereka untuk mengambil contoh dari jurnaljurnal yang sudah terpercaya. Selain itu, ada baiknya untuk mahasiswa yang ingin mempublikasikan hasil penelitian mereka untuk mendiskusikan dan mengevaluasi hasil tulisan mereka dari sudut pandang ahli bisa dosen ataupun pengulas jurnal dan merevisi tulisan mereka berdasarkan masukan atau kritik yang didapat.

\section{DAFTAR PUSTAKA}

Abdollahpour, Z., \& Gholami, J. (2018). Rhetorical Structure of the Abstracts of Medical Sciences Research Articles. La Prensa Medica Argentina, 105(2), 1-5.

Andrade, C. (2011). How to write a good abstract for a scientific paper or conference presentation. Indian Journal of Psychiatry, 53(2), 172-175. https://doi.org/10.4103/0019-5545.82558.

Ary, D., Jacobs, L. C., Sorensen, C., \& Razaiveh, A. (2014). Introduction to Research in Education (9th ed.). Londong:Wadsworth.

Bunton, D. (2002). Generic moves in Ph.D. thesis Introductions. In Academic Discourse (pp. 57-75). Routledge. https://doi.org/10.4324/9781315838069-11.

Çakır, H. (2005). Native and Non-Native Writers' Use of Stance Adverbs in English Research Article Abstracts. Open Journal of Modern Linguistics, 6, 85-96. https://doi.org/10.4236/ojml.2016.62008.

Fadhly, F. Z., Emzir, E., \& Lustyantie, N. (2018). Exploring Cognitive Process of Research Topic Selection In Academic Writing. English Review: Journal of English Education, 7(1), 166. https://doi.org/10.25134/ erjee.v7i1.1535.

Foote, M. (2006). Some concrete ideas about manuscript abstracts. Chest Journal, 129(5), 1375-1377. https://doi. org/10.1378/chest.129.5.1375.

Forester, B. R., Lasky, J. R., Wagner, H. H., \& Urban, D. L. (2018). Comparing methods for detecting multilocus adaptation with multivariate genotype-environment associations. Molecular Ecology, 27(9), 2215-2233. https://doi.org/10.1111/mec.14584.

Georgia Mansion University. (2020). Writing an Abstract. The Writing Center. https://writingcenter.gmu.edu/ guides/writing-an-abstract.

Hyland, K. (2009). Academic Discourse: English In A Global Context (Continuum Discourse). London, $\mathrm{UK}$ :Continuum.

Hyland, K. (2013). Disciplinary Discourses: Social Interactions in Academic Writing. University of Michigan Press. https://muse.jhu.edu/book/22712.

Hyland, K., \& Tse, P. (2005). Hooking the reader: A corpus study of evaluative that in abstracts. English for Specific Purposes, 24(2), 123-139. https://doi.org/10.1016/j.esp.2004.02.002. 
Jalalian, M. (2012). Writing an eye-catching and evocative abstract for a research article: a comprehensive and practical approach. Electronic Physician, 4(3), 520-525. https://doi.org/10.14661/2012.520-524.

Murray, R., \& Newton, M. (2008). Facilitating writing for publication. Physiotherapy, 94, 29-34. https://doi. org/10.1016/j.physio.2007.06.004.

Papanas, N., Georgiadis, G., Maltezos, E., \& Lazarides, M. K. (2012). Writing a research abstract: Eloquence in miniature. International Angiology: A Journal of the International Union of Angiology, 31(3), 297302. https://www.researchgate.net/publication/225064376_Writing_a_research_abstract_Eloquence_in_ miniature.

Paris, D., \& Winn, M. T. (2018). Humanizig Research: Decolonizing Qualitative Inquiry with Youth and Communities. In Humanizig Research: Decolonizing Qualitative Inquiry with Youth and Communities. SAGE Publications, Inc. https://doi.org/10.4135/9781544329611.

Prihatmi, T. N. (2017). English Academic Writing Bagi Mahasiswa di Institut Teknologi Nasional Malang: Hambatan dan Solusi. Prosiding SENIATI, cV54.4. https://ejournal.itn.ac.id/index.php/seniati/article/ view/1866.

Slade, C., \& Perrin, R. (2010). Form and Style: Research Papers, Reports, Theses (13th Edition). Cambirdge, MA:Wadsworth Cengage Learning.

Supatranont, P. (2012). Developing a Writing Template of Research Article Abstracts: A Corpus-Based Method. Procedia - Social and Behavioral Sciences, 66, 144-156. https://doi.org/10.1016/j.sbspro.2012.11.256.

Swales, J. M. (2011). Aspects of Article Introductions (Michigan Classics). Michigan: University of Michigan Press ELT.

Walden University. (2020). Abstracts - Common Assignments - Academic Guides at Walden University. Walden University. https://academicguides.waldenu.edu/writingcenter/assignments/abstracts. 